\title{
Nutraceutical potential of Ficus roxburghii an underutilized fruit of Sikkim Himalayas
}

Yamuna Pandey*

Department of Horticulture, Sikkim University, Gangtok (Sikkim ), India

S. Upadhyay

Department of Horticulture, Sikkim University, Gangtok (Sikkim ), India

S. Manivannan

Department of Horticulture, Sikkim University, Gangtok (Sikkim ), India

L. Sharma

Department of Horticulture, Sikkim University, Gangtok (Sikkim ), India

S.S. Bhatt

Himalayan Institute of Pharmacy and Research, Dehradun (Uttarakhand), India

${ }^{*}$ Corresponding author. E-mail: yamunapandey1988@gmail.com

\begin{abstract}
:
Ficus roxburghii, "Elephant ear fig "or wild fig is one of very popular fruits found growing wild in the hills of North Eastern and North Western Himalayan region. The fruit of wild fig has also been used as medicine by the tribal people of Sikkim and other states of India. Keeping this in view, the present study was conducted at Laboratory of Department of Horticulture, Sikkim University, Sikkim to access the different nutraceuticals properties as nutritional constituent like protein, fat, fibre, carbohydrate and energy value, mineral content viz. $\mathrm{Ca}, \mathrm{K}, \mathrm{Mg}, \mathrm{Na}, \mathrm{Zn}, \mathrm{Co}, \mathrm{Mo}, \mathrm{Fe}, \mathrm{Mn}$ and phytochemical content such as total phenols, flavonoid, ascorbic acid, anthocyanin and total carotenoids of $F$. roxburghii. The results of present study revealed that fruit of $F$. roxburghii contains significant amount of nutritional, mineral and phytochemical properties viz. protein $(3.00 \pm 0.06 \%)$, fat $(0.13 \pm 0.04 \%)$, fibre $(3.06 \pm 0.02 \%)$, carbohydrate $(90.81 \pm 0.44 \%)$, energy value (376.45 \pm 1.44$)$, Ca (23.69 \pm 1.7$), \mathrm{Mg}(73.09 \pm 2.1), \mathrm{K}(819.64 \pm 12.54)$, Mo (0.58 \pm 0.06$)$, $\mathrm{Na}(6.73 \pm 1.2), \mathrm{Zn}(0.34 \pm 0.10)$. Fe $(26.55 \pm 2.8), \mathrm{Cu}(4.22 \pm 0.20), \mathrm{Mn}(7.11 \pm 0.11)$, total phenols $(4.13 \pm 0.52 \mathrm{mg} \mathrm{GAE} / \mathrm{G}$ ), total flavonoid (3.10 $\pm 0.09 \mathrm{mg} \mathrm{GAE} / \mathrm{G}$ ), ascorbic acid $(3.36 \pm 0.27 \mathrm{mg} \mathrm{GAE} / \mathrm{G})$, anthocyanin $(1.13 \pm 0.15 \mathrm{mg} \mathrm{GAE} / \mathrm{G})$ and total carotenoids $(0.68 \pm 0.10 \mathrm{mg} \mathrm{GAE} / \mathrm{G})$. It may be concluded that the fruit of $F$. roxburghiiis rich in nutraceuticals and must be incorporated in our balanced diet.
\end{abstract}

Keywords: Ficus roxburghii, Minerals, Nutritional, Nutraceuticals, Phytochemicals

\section{Article Info}

DOI:10.31018/jans.v10i3.1725

Received: May 16, 2018

Revised: June 30, 2018

Accepted: July 10, 2018

\section{How to Cite}

Pandey, Y. et al. (2018).

Nutraceutical potential of

Ficus roxburghii an underutilized fruit of Sikkim Himalayas. Journal of Applied and Natural Science, 10(3): $876-880$

\section{INTRODUCTION}

Ficus roxburghii is a wild fig belonging to Moraceae family. Plant is small, wide-spreading, evergreen tree growing up to 12 meters tall. Roxburghii fig is also known as elephant ear fig because the plant has very large, ovate leaves that can be up to $55 \times 30 \mathrm{~cm}$. The tree is harvested from the wild for its edible fruit, medicinal uses and its leaves, which are used as plates. The plant is grown in India and from Myanmar to Vietnam and SW China and Brazil for its edible fruits. The fruit is available almost round the year usually eaten raw or cooked. The fruit is depressed-globose to pear-shaped, up to $8 \mathrm{~cm}$ in diameter. The roasted fruit is used in the treatment of diarrhoea and dysentery. The fruits are claimed to have an anti-diabetic properties but no proper scientific evidence have been found yet. A huge biodiversity of underutilized fruits and vege- tables exists in Sikkim Himalaya but their potentials and proper utilization has still not fully exploited. F. roxburghii is one of those valuable underutilized fruits growing wild in Sikkim is being claimed to be rich in nutraceuticals properties. Nutraceutical is associated with the combination of nutrient, minerals, phytochemicals as bio active substances which are of known therapeutic values which substantially contribute towards human health as a mode of balance diet and therapeutic drugs. Underutilized species having high nutritional and nutraceuticals values are major source of protective food which occurs naturally and always played vital role in nutritional security for large section of rural tribes. Ficus species are rich source of polyphenolic compounds and flavonoids which are responsible for strong antioxidant properties that helps in prevention and treatment of various oxidative stress related diseases (George et al., 2016). Keeping the above points into con- 
sideration, the nutraceuticals constituents viz. nutritional constituents (protein, fat, fibre, available carbohydrate and energy value), minerals, total, phenols, flavonoids, ascorbic acid, anthocyanins and total carotenoids of $F$. roxburghii were determined.

\section{MATERIALS AND METHODS}

The present investigation on Nutraceuticals potential of Ficus roxburghii, an underutilized fruit of Sikkim Himalayas." was carried out at Laboratory of Department of Horticulture, Sikkim University during the year 2014-2017. Experiment was conducted on matured fruits of $F$. roxburghii which were directly collected from the forest area of different region of Sikkim Himalayas. Nutritional component viz. crude protein, crude fat, crude fibre, available carbohydrate, energy value, minerals and phytochemicals viz. total phenols, flavonoid, ascorbic acid, anthocyanin and total carotenoids were estimated using standard method of chemical analysis which are mentioned below:

Nutritional analysis

Crude protein: The crude protein was estimated by Lowry's method (Lowry et al., 1951) by using UV/VIS Spectrophotometer, Perkin Elmer, Lambda 35 UV/VIS spectrometer.

Crude fat: Crude fat content was determined by Soxhlet principle with slight modification (A.O. A.C, 1990). Fat from the oven dried fruit sample was extracted in essential oil extractor (model no. Socsplus-SCS 06 DLS, PELICAN) using petroleum ether as solvent then ether is evaporated and determined the weight of the fat recovered using following Eq. 1.

Crude fat $(\%)=W_{2}-W_{1} /$ Weight of the sample $X 100$ ........Eq. 1

Crude fibre: Crude fibre was analyzed using fibre estimation system, model no Fibra plus-FES 04 AS DLS, PELICAN.2 $\mathrm{g}$ of moisture and fat free sample were taken in the crucibles then it was loaded in the instrument. $150 \mathrm{ml}$ of $1.25 \%$ of $\mathrm{H}_{2} \mathrm{SO}_{4}$ was added from the top and boiled at $500^{\circ}$ $\mathrm{C}$ for 30 minutes. Once the boiling was completed the reagents was drained out with the help of fibra flow then $150 \mathrm{ml}$ of $1.25 \% \mathrm{NaOH}$ was added from the top and heating the sample at $400^{\circ} \mathrm{C}$ for 45 minutes which led to digestion of sample. After completion of digestion reagents was drained out and residue was dried in hot air oven at $90-100^{\circ}$ $\mathrm{C}$ and cooled and weighed the dried residue $\left(\mathrm{W}_{1}\right)$ then the residue was kept in pre-weighed porcelain crucible and put in the muffle furnace for ashes at $600^{\circ} \mathrm{C}$ in 3 hours then it was cooled and weighed $\left(\mathrm{W}_{2}\right)$. Crude fibre content was expressed as percentage loss in weight on ignition (A.O.A.C, 1990) and calculated using following Eq. 2:

Crude fibre $(\%)=W_{1}-W_{2}$ Weight of the sample $X$ 100

........Eq. 2

Available carbohydrate: The percentage of available carbohydrate was calculated by: $100-$ (Percentage of ash + Percentage of fat + Percentage of fibre + Percentage of protein) (A.O.A.C, 1990).

Energy value/nutritive value: The energy value in kilocalorie per gram (Kcal/g) was determined by multiplying the percentage of crude proteins, crude fat and carbohydrate by the recommended factor 4,9 and 4 , respectively and then taken the sum of values. The value was then converted to kilojoules by multiplying with 4.2 (A.O.A.C, 1990). Energy value $(\mathrm{Kcal} / \mathrm{g})=(\mathrm{CP} \times 4)+(\mathrm{CF} \times 9)+$ (Carb. x 4)

Ash content: Ash content was determined by following the method of (A.O.A.C, 1990)For thiscrucible were kept in a muffle furnace at $600^{\circ} \mathrm{C}$ for $1 \mathrm{~h}$. Then they were transferred from furnace and cooled to room temperature and weighed $\left(\mathrm{W}_{1}\right)$ asquickly as possible to prevent moisture absorption. $2 \mathrm{~g}$ dried fruit sample was takenin crucible and placed in a muffle furnace at $600^{\circ} \mathrm{C}$ for $6 \mathrm{~h}$. Then crucible wastransferred to cooled at room temperature and weighed $\left(\mathrm{W}_{2}\right)$, Then the percentage of ash was calculated byusing the following Eq. 3:-

Ash (\%) $=W_{2}-W_{1}($ Wt. of ash) Weight of the sample X $100 \quad$.....Eq. 3

Mineral analysis: ICP-MS (Inductively Coupled Plasma Mass Spectrophotometry) Perkin Elmer Nex ION 300X was used for estimation of some mineral elements. Digested samples were analyzed for the ionic constitution using multi elements standards for detecting the elements such as $\mathrm{Ca}, \mathrm{Fe}, \mathrm{Mg}, \mathrm{Mn}, \mathrm{Mo}, \mathrm{Na}, \mathrm{Zn}$. The micro wave digestion system (Anton par microwave 3000) was used for sample digestion as $0.5 \mathrm{gm}$ sample were along $9 \mathrm{ml}$ of $69 \%$ nitric acid and $2 \mathrm{ml} \mathrm{HCl}$ were added into the digestion tube and run the instrument for 40 minutes. The digested samples were then transferred into $50 \mathrm{ml}$ volumetric flask when the temperature of the sample was reduced and distilled water was added for making the volume of $50 \mathrm{ml}$. The liquid sample was transferred into narrow mouth bottle until the minerals were determined in ICP-MS. The values of the elements were expressed as $\mu \mathrm{g} / \mathrm{L}$.

Nutraceutical analysis

Extraction of fruit sample: The matured fruits of F. roxburghii collected from different places of Sikkim were washed and cleaned thoroughly in running water. Fruits were then chopped into small pieces and dried at 105 o $\mathrm{C}$ for 48 hours in hot air oven. Dried sample were then grind into fine powder using Willey mill and 5 gram of sample each sample was extracted using $50 \mathrm{ml}$ solvent $\left(80 \%\right.$ methanol) for 12 hours at $60^{\circ} \mathrm{C}$ temperature in Soxhlet apparatus (essential oil extractor: model no. Socsplus-SCS 06 DLS, PELICAN). After completion of boiling, temperature was increased to $150^{\circ} \mathrm{C}$ for $45 \mathrm{~min}$ to evaporate the sol- 
vent. The extract were concentrated to dryness in rotary evaporator under reduced pressure and weighed. The extracts were then diluted with known volume $(\mathrm{mg} / \mathrm{ml})$ of methanol in air tight small container and kept under refrigerator at $4^{\circ} \mathrm{C}$ until analysis.

Total phenols: The concentrations of total phenol content of methanol extract of fruits were determined in UVIVIS Spectrophotometer (Perkin Elmer, Lambda 35 UVIVIS spectrometer) by employing the method (Singleton et al., 1999) with minor modification involving Folin-Ciocalteau Reagentas as oxidizing agent and gallic acid as standard.

Total Flavonoid: The aluminum chloride assay was used for the determination of the total flavonoid content of the fruit extracts according to the method described by (Kumaran and Karunakaran, 2007) with slight modifications in UV/VIS Spectrophotometer (Perkin Elmer, Lambda 35 UV/VIS spectrometer).

Ascorbic acid: The ascorbic acid was determined by reduction of 2, 6-dichlorophenol indophenols dye by ascorbic acid as procedure given by(A.O.A.C, 1980) Ten (10) $\mathrm{ml}$ of juice was taken and blended with $0.4 \% \mathrm{HPO}_{3}$ and finally volume was made up to $100 \mathrm{ml}$ with $0.4 \% \mathrm{HPO}_{3}$ and then $10 \mathrm{ml}$ aliquot was titrated against standardized dye to obtain a pink colour which persists at least for 15 seconds. Ascorbic acid was expressed regarding mg per $100 \mathrm{gm}$ pulp by using Eq. 4:

Ascorbic acid (mg/100 g pulp) =Dye factor $x$ titre reading $x$ dilution / Weight of sample $X 100$ ............Eq. 4 Anthocyanin content: Anthocyanin content was determined by the method described by (Srivastava et. al., 2003) with some modification. Sample was extracted by blending $10 \mathrm{~g}$ of finely ground sample with $10 \mathrm{ml}$ of $95 \%$ ethenolic HCL and centrifuged at $10000 \mathrm{rpm}$ for 20 minutes then supernatant was collected and transferred into $100 \mathrm{ml}$ volumetric flask and volume was made up to the mark and solution was stored in the refrigerator at $4^{\circ} \mathrm{C}$ until analysis. The optical density of the aliquot was determined at $530 \mathrm{~nm}$ in UV/VIS Spectrophotometer (Perkin Elmer, Lambda 35 UVIVIS spectrometer). The value of total Anthocyanin content was expressed as mg/100 gram. Calculation was done by using Equation No. 5.

Table 1. Nutritional content of Ficus roxburghii.

\begin{tabular}{lll}
\hline S.N. & Parameters & Values (\%) \\
\hline 1. & Crude protein & $3.00 \pm 0.06$ \\
2. & Crude fat & $0.13 \pm 0.04$ \\
3. & Crude fibre & $3.06 \pm 0.02$ \\
4. & Ash & $2.99 \pm 0.41$ \\
5. & Carbohydrate & $90.81 \pm 0.44$ \\
6. & Nutritive value $(\mathrm{Kcal} / 100 \mathrm{~g})$ & $376.45 \pm 1.44$ \\
\hline
\end{tabular}

${ }^{*}$ Each value is an average of 3 determinations.
Total O.D/100g =O.D. x volume made up x100/ weight of sample $\mathrm{X} 100 \quad$........Eq. 5 Total anthocyanin (mg/100 g) =Total O.D./ $100 \mathrm{~g} / 98.2$

Total carotenoids: One gram of sample was weighed and grinds it with acetone using acid and alkali washed sand in a pestle and mortar. The extract is decanted into a conical flask. Continue the extraction till the residue was colourless. The acetone extract was transferred to a separating funnel containing $10-15 \mathrm{ml}$ of petroleum ether and mixed gently. About $25 \mathrm{ml}$ of $5 \%$ sodium sulphate solution was added. Shaked it and kept for sometimes and yellow colour pigment is transferred into the petroleum ether later. Collected the layer in a volumetric flask and separated acetone layer containing $5 \%$ sodium sulphate. Kept on adding $15 \mathrm{ml}$ petroleum ether to the acetone layer containing $\mathrm{Na}_{2} \mathrm{So}_{4}$ until thecolour gets transferred into the petroleum ether and measured the colour intensity at $452 \mathrm{~nm}$ in a spectrophotometer. And the total carotenoids content was calculated using Equation No. 6:

Total catotenoids $(\mathrm{mg} / 100 \mathrm{~g})=3.857 \times$ O.D. $\times$ Volume made up $\times 100 /$ weight of the sample $X 100$ ........Eq. 6

Statistical analysis: All the experiments were carried out in triplicates and data were expressed as mean \pm standard deviation.

\section{RESULTS AND DISCUSSION}

Nutritional constituent: Details in respect to nutritional constituents of Ficus roxburghii fruits are summarize in Table 1. The present study revealed that the fruit of $F$. roxburghii contains $3.00 \pm 0.06 \%$ crude protein which was similar to the finding as revealed by (Bhutia, 2013) while analyzing fruit of F. roxburghii. The variable range of protein content from $2.65 \%$ to $5.58 \%$ in different indigenous fruits of Sikkim. As far as crude fat is concerned it was found to be less as it was present in minute quantity i.e. $0.13 \pm 0.04 \%$ in fruit pulp (Sundriyal and Sundriyal, 2003). Whereas, Rai et al., (2005) noted 0.9 $\%$ crude fat content in Ficus hookeriana of Sikkim Himalaya which is similar to our finding. Crude fibre content in present study was observed as $3.06 \pm 0.02 \%$. Fibre is also known to reduce risk of

Table 2. Mineral content of Ficus roxburghii.

\begin{tabular}{lll}
\hline S. N. & Minerals & Values $(\boldsymbol{\mu g} / \mathbf{L})$ \\
\hline 1 & Calcium & $23.69 \pm 1.7$ \\
2 & Magnesium & $73.09 \pm 2.1$ \\
3 & Potassium & $819.64 \pm 12.54$ \\
4 & Molybdenum & $0.58 \pm 0.06$ \\
5 & Sodium & $6.73 \pm 1.2$ \\
6 & Zinc & $0.34 \pm 0.10$ \\
7 & Iron & $26.55 \pm 2.8$ \\
8 & Copper & $4.22 \pm 0.20$ \\
9 & Manganese & $7.11 \pm 0.11$ \\
\hline
\end{tabular}

*Each value is an average of 3 determinations 
Table 3. Phyto-chemical constituent of Ficus roxburghii.

\begin{tabular}{lll}
\hline S.N. & Parameters & Composition \\
\hline 1. & Total phenol $(\mathrm{mg} \mathrm{GAE} / \mathrm{g})$ & $4.13 \pm 0.52$ \\
2. & Total flavonoid $(\mathrm{mg} \mathrm{QE} / \mathrm{g})$ & $3.10 \pm 0.09$ \\
3. & Ascorbic acid $(\mathrm{mg} / 100 \mathrm{~g})$ & $3.36 \pm 0.27$ \\
4. & Anthocyanin $(\mathrm{mg} / 100 \mathrm{~g})$ & $1.13 \pm 0.15$ \\
5. & Total carotenoid $(\mathrm{mg} / 100 \mathrm{~g})$ & $0.68 \pm 0.10$ \\
\hline
\end{tabular}

${ }^{*}$ Each value is an average of 3 determinations.

some of the world's most prevalent disease like obesity, diabetes, high blood cholesterol, cardiovascular disease, and numerous gastrointestinal disorders (Venn and Mann, 2004);(Tungland and Meyer, 2002). The value of ash content was recorded as $2.99 \pm 0.4 \%$. The estimated value of carbohydrate in present study was recorded as $90.81 \pm 0.44 \%$. A relative species Ficus palmata fruit was screened and carbohydrate content was recorded as $20.78 \%$ (Saklani et al., 2012) which is lesser than that of current finding. The nutritive value or calorific value of $F$. roxburghii fruit was found to be $376.45 \pm 1.44 \mathrm{Kcal} / 100 \mathrm{~g}$.

Mineral composition: The mineral composition is an important for reliable nutrient informa-tion and its pivotal role in human life provides healthy growth (Anuradha et al., 2013). The data pertaining to mineral composition of Ficus roxburghii fruits are presented in Table 2. Out of nine minerals quantified in the fruit of $F$. roxburghii potassium was highest i.e.819.64 $\pm 12.54 \mu \mathrm{g} / \mathrm{L}$ and Zinc $(0.34 \pm 0.10 \mu \mathrm{g} / \mathrm{L})$ and Molybdenum (0.58 \pm $0.06 \mu \mathrm{g} / \mathrm{L})$ were lowest. Good amount of calcium, magnesium and iron was also noted i.e.23.69 \pm $1.7 \mu \mathrm{g} / \mathrm{L}, 73.09 \pm 2.1$ and $26.55 \pm 2.8$, respectively. As human body is not capable to synthesize vitamins, the consumption of diets containing these compounds will be beneficial. Kalita et al. (2014) reported that $M$. roxburghii and S. spirale were having highest amount of potassium (23.8g $\%$ and $23.3 \mathrm{~g} \%$ ), followed by P.pedicellatumand G. hirta. Seal et at. (2014) reported highest potassium content $(6.14 \pm 0.16$ to $57.22 \pm 0.84 \mathrm{mg} / \mathrm{g})$ among other minerals while analyzing wild fruits.

Phytochemical constituents: Phytochemical constituents such as total phenols, total flavonoid, ascorbic acid, anthocyanin and total carotenoid are presented in table 3 . The total phenol content was found to be $4.13 \pm 0.52 \mathrm{mg} \mathrm{GAE} / \mathrm{g}$ whereas, the observed value of total flavonoid was $3.10 \pm 0.09 \mathrm{mg} Q E / \mathrm{g}$. likewise the ascorbic acid, anthocyanin and total carotenoide were found in a range of $3.36 \pm 0.27 \mathrm{mg} / 100 \mathrm{~g}, 1.13 \pm 0.15 \mathrm{mg} / 100 \mathrm{~g}$ and $0.68 \pm 0.10 \mathrm{mg} / 100 \mathrm{~g}$, respectively. Prakash et al. (2012) found the total phenolic contents (TPC) of $7.3 \mathrm{mg} / 100 \mathrm{~g}$ in Ficus hookeri, fruits. Aberoumand (2011) evaluated the total phenolic contents in eight plant foods viz. Alocacia indica Sch, Eulophia Ochreata Lindl, Momordica dioicia Roxb., Asparagus officinalis, Chlorophytum comosum,
Codia myxa, Portulaca oleracia and Solanum indicum were used as traditional vegetables and fruits. Their phenolic contents ranged from 0.87 to $7.02 \mathrm{mg}$ gallic acid/g. The nutraceuticals value of any plant mainly depends upon the antioxidative properties. Certain compounds like total phenol, total flavonoid, ascorbic acid, anthocyanin, carotenoids etc. can enhance the antioxidant activity.

Nutraceutical content of $F$. roxburghii have found to be rich in major nutrients and phytochemicals and it is also found to be superior as compared to other commercial fruits.

\section{Conclusion}

The present investigation suggests that the fruit of Ficus roxburghii is a major source of nutritional, mineral, phytochemicals and phenolic compounds. The fruit of $F$. roxburghii found to be rich in nutritive constituents such as protein $(3.00 \pm 0.06$ $\%)$, carbohydrate $(90.81 \pm 0.44 \%)$, crude fibre $(3.06 \pm 0.02)$. Mineral like Potassium content $(819.64 \pm 12.54 \mu \mathrm{g} / \mathrm{L})$ of the fruit was also observed in good amount and the phyto chemicals constituents like total phenols, flavonoid, Ascorbic acid are also observed in minute quantities. Therefore, the fruits of $F$. roxburghii can be used as a source of nutraceuticals and can be supplemented through a balanced diet which could be much safer and cheaper than commercially available fruits.

\section{REFERENCES}

1. AOAC (1990). Official Methods of Analysis. $15^{\text {th }}$ Edn., Association of Official Methods of Analytical Chemists, Washington, DC., Arlington, Virginia, USA., ISBN: 0-935584-42-0

2. AOAC (1980). Official Method of Analysis. Association of Official Analytical Chemist, A.O.A.C, Benjamin Franklin Station, Washington, DC.

3. Aberoumand, A. (2011). Survey on some food plants as sources of antioxidants. Innovative Romanian Food Biotechnology. 8: 22-25.

4. Anuradha, V., Praveena, A., Sanjayan, K.P. (2013). Nutritive analysis of fresh and dry fruits of Morindatinctoria. Int. J. Curr. Microbiol. App. Sci., 2(3):65-74.

5. Bhutia, K. D. (3013). Studies on the physicochemical characteristics and utilization aspects of some indigenous minor fruits of Sikkim. Ph. D thesis. Department of Pomology and Post Harvest Technology. Uttar Banga Krishi Vishwavidyalaya. Pp. 203.

6. George, M., Joseph, L. and Nimisha M. P. (2016).Ficus auriculata; A Pharmacological Update. Int.J.Curr.Res.Aca.Rev.4(7): 26-31.

7. Kalita, P., Tag, H., Sarma, H.N. and Das, A.K. (2014). Evaluation of Nutritional Potential of Five Unexplored Wild Edible Food Plants from Eastern Himalayan Biodiversity Hotspot Region (India). Int. J. Biol. Food, Veterinary Agril Eng.8: 207-210.

8. Kumaran, A. and Karunakaran, R. J. (2007) In-vitro antioxidant activities of methanol extract of five phyllanthus species from India. LWT-Food Sci. Technol.40: 344-352. 
9. Lowry, O.H., Rosebrough, N.J., Farr, A. L., and Randall, R.J. (1951). Protein measurement with the Folin Phenol Reagent. J. Biol. Chem.193: 265 -275.

10.Prakash, D., Upadhyay, G. Gupta, C., Pushpangadan, P. and Singh, K.K. (2012). Antioxidant and free radical scavenging activities of some promising wild edible fruits. Int. Food Res. J. 19(3):11091116.

11.Rai, A.K., Sharma, R.M. and Tamang J.P. (2005). Food value of common wild plants of Sikkim. Journal of Hill research.18(2): 99-103.

12.Saklani, S., Chandra, S. Mishra, A. P. and Badoni, P. P. (2012). Nutritional Evaluation, Antimicrobial Activity And Phytochemical Screening Of Wild Edible Fruit Of MyricaNagiPulp. Intl. J. Pharmacy and Pharmaceutical Sci. 4(1): 407-411.

13.Seal, T., Pillai, B. and Chaudhuri, K. (2014). Nutritional Potential of wild edible fruits, traditionally used by the local people of Meghalaya state in India. Indi- an Journal of Natural Product and Resources. 5(4): 359-364.

14.Singleton, V.L., Orthofer, R., Lamuela-Raventos, R.M.(1999). A.nalysis of total phenols and other oxidation substrates and antioxidants by means of FolinCiocalteu reagent. Methods Enzymol. 299: 152-178.

15.Srivastava, R. P. and Kumar, S. (2003). Fruits and vegetable preservation. International Book Distributing Company, Lucknow- 226 004, India, 474p.

16.Sundriyal, M. and R.C. Sundriyal. (2003). Underutilized edible plants of the Sikkim Himalaya: Need for domestication. Current Science, 85: 731-736.

17.Tungland, B.C. and Meyer, D. (2002). Non digestible oligo- and polysaccharides (dietary fiber): their physiology and role in human health and food, Comp Rev Food Sci Food Safety. 3: 73-92.

18.Venn, B.J., Mann, J.I. (2004). Cereal grains, legumes and diabetes. Eur J Clin Nutr.58(11):1443-61. 